\title{
Elements of Ibsen`s Drama: Reversion, Anagnorisis and Catastrophe
}

\begin{abstract}
Dr. Rregjina Gokaj
Muhamed Dervishi

University "Aleksandër Moisiu", Durrës

E-mail: rregjinagokaj@gmail.com

Doi:10.5901/ajis.2013.v2n4p303

Abstract.

This paper will be focused mainly in the elements of symbolic drama of Henrik Ibsen, Brand and Peer Gynt, and When We Dead Awaken. Most scholars consider them as unrealized work of his. A close review of these plays requires the necessity of its connection with Aristotelian principles of tragedy as well as in many other dramas of Ibsen. The element of reversion and recognition finds place in the most magnificent works of great dramatist, and no doubt, it is present in Ibsen's drama. However, the most important part is when reversion encounters recognition, which is the unique feature of this drama, which interweaves in it the complication of the relation between the subject and the characters. In the combination of stage metaphor with the textual metaphor, one can notice the animal lust, the pure and sublime love, the sacrificing life, the betrayed art, which try to survive although too late for that. This is because artistic visions are unifying and conflicting voices in the last stage metaphor of the plays.
\end{abstract}

Keywords: Anagnorisis, catastrophe, reversion, character, symbol, metaphor.

\section{Reversion and the subject in the symbolic drama}

The symbolic drama of Henric Ibsen has kept the criticism alive since the introduction of the drama titled "Brand", and later Peer Gynt, to further continue with his realistic dramas. His latest drama When We Dead Awaken, has been less studied compared to other dramas. Even in critical approaches, the language used was much more debatable than his work aesthetics or its construction.

In general, critics have brought this drama to public attention as an unrealized work because of its length, vague message or lack of creative imagination, which they relate to the age when it was written (Ibsen was 71 years old when he brought the drama). The beginning of twentieth century brought a radical change in terms of critics access to Ibsen and consequently to his latest drama. In this period another way of writing was noticed, differently called modern, which went from modernism to metafinction and the development of literary theory went from the new criticism to deconstruction, new historicism, and gender studies.

At first critics discussed about drama in its classic context, seeing it as the current reaction of the past events, but an interesting approach is the re-treatment of the work based on the symbolism of myth in the present action, while past actions are seen in the construction of this very act in the present.

\section{Reversion in Ibsen's drama}

Review of that drama requires the necessity of its connection with Aristotelian principles of tragedy as well as in many other dramas of Ibsen. The element of reversion and recognition is found in the most magnificent works of great dramatist, and no doubt it is present in Ibsen's drama.

We mainly find it in the drama When We Dead Awaken, as one of his most symbolic and multidimensional dramas estimated for its most perfect synthetic power, laconism and conciseness ever achieved by the author. 
Among the main features of tragedy, as Aristotle puts it in his work Poetics, are reversion and discovery or Recognition (peripeteia and anagnorisis) as two elements of the subject that should result from its structure in such a way that that event, which has already happened, makes the outcome inevitable or very likely to happen. Chapter X: 11 of Poetry clearly shows his principle:

'reversion is a change of the situation from the opposite side, ... this difference is, as we say inevitable or very likely to happen - such as the man to Oedipus, who came to make Oedipus happy and to remove the anxiety about his parents by saying who is the mother, something which completely changed the situation. While recognition (anagnorisis) is the change that goes from unknown to known, which results either in friendship or enmity to those who are destined for good luck or bad luck. (Aristotle. Poetics. Loeb Classical Library. Chapter X:11.)

Oedipus the King is the classical drama of shocking and explosive secrets, where in any sequence a hidden bomb is expected to explode by the discovery of the unknown, of the secret. At Sophocles, like in Ibsen, fatality makes sense on all the action in the play, not just as an idea but as complex internal feelings.

Reversion at the drama When We Dead Awaken comes across at its protagonist, Rubek, who can not be considered classical hero, because he embodies at first the conflict between Life and Art. Although Professor Rubek betrayed the idea of art when introduced the female and male element in his version of the work The Day of Resurrection, he fails to realize his idea of life, which is reflected in the wedding with Maja. Reversion can not be considered to have happened in the imagined adventure up the mountain with Irene, as it is more fiction (which never finds room); or furthermore, the fantasy to redo what the couple believes it has done in the past. Such an analysis leads us to think that the transition from unknown to known occurred at the beginning of the drama.

Irene, the other protagonist in the drama, is also not developed as a character, on the contrary she seems to have been placed to hypothesize a lost life somewhere and sometime. From her first appearance, Irene is a symbol of death, mentioned by Rubek when she appears on stage:

Rubek: a little lady, dressed in a white robe - cream of cashmere, comes from the rear of the hotel, followed by a NUM dressed in black, with a silver cross hanging from a chain in the her chest. She walks through the park, towards the pavilion, to the left. Her face is pale, her features are solid and plastic; her eyes are small and seem to fix without really looking at you. Her dress extends to the ground and runs over her body in a regular plaits. On the head, neck, chest, shoulders, and her arms she wears a white opalescent scarf. She keeps her arms crossed on the chest. She holds this unwavering position; she walks with firm and careful steps. (McFarlane, J. W. 1977: 247-248).

Description which Rubek brings Irene to the reader, at first gives the impression of a cold and silent statue, which is unchanged in its features. Even Rubek's relation with his wife, Maja, is given as a static, undeveloped relation, where emotion has stopped long ago since its starting point. Here one can notice the lack of dramatic space for the vicissitude or reversion, as the relation between the character and the subject has no action. An obvious comparison of this character correlation may be made here - subject at the other tragic drama Ghosts, where in the analysis of Mrs. Alving we see that being the protagonist she behaves as an ideal tragic hero of the work. At Ghosts we have vicissitude as well as anagnorisis - visible elements and at the function of each other mentioned at the above analysis of the play in question.

When We Dead Awaken consists of a minor subject based on fragments of previous 'mini-subjects ' which are not resolved or have fallen in despair. These failures occasionally warn us, thus forming the attitude at the moment when the work starts.

\section{The subject of the work in a triagular connection}

The subject of the work is divided in two relations: firstly, the relation between Professor Rubek and Maja, secondly the relation between Irene and Ulfajm. These two relations generate two interesting triangular relations. The first triangle is based on the cold and uninspiring relation between Rubek and Maja, a failed marriage, a failure accepted by both of them, where Ulfajm is added as a third element of this triangle. Ulfajm, 
in his hunting garment, boots and his hat with a feather at the top, gives the impression of a primitive and not emancipated person. Maja compares him to a baby deer that hunts eagles, wolves, wild deer and surprisingly women when given the opportunity, moreover he eats raw meat. Not surprisingly Ibsen introduces this strange food element in the context of the nineteenth century. This is to give meaningful signs that we are dealing with an absurd and ridiculous character, thus presenting us a parody of vulgar vitality. The element of discovery or recognition (anagnorisis) emerges when Ulfajm tells that he has previously known professor Rubek and now he is re-knowing him, Rubekun, the famous sculptor. And what's more, he is compared to him in Maja's eyes in relative terms.

Ulfajm: we both work on hard material, Madam - your husband and me. He 'grapples' with marble blocks. I think so too. And I 'grapple' with strained and quixotic nerves of bears.

Maja's provocative behavior with Ulfajm makes Rubek, the honored professor, feel dishonored and betrayed by his wife, as she accepts to climb up the mountain to enjoy the cleanliness and purity of nature from every stain of people. Rubek does not accept this ubiquitous ordinary role of a betrayed spouse, so it looks like he himself wants to be involved in a 'ménage à trois'. (McFarlaine, J.W. 1977:252) The applied idea results in another reversion, exactly when Rubek recognizes Irene in the mountain, his former muse, his lost model.

The second triangular connection, even more interesting, has to do with Rubek desire to rediscover the key of the 'small box' with all his visions, which he fails to open. (McFarlaine, J.W. 1977:274). This implies the reunion of Rubek with Irene, his highly desired former model, with whom he wants to reach the top and start a new life. 'Dawn will come and shine more on both of us' implies the tragic triangular subject, where the two apexes are Irene and Rubek, while the third apex is their 'child', the sculpture of Rubek: Day of Resurrection. The symbol, as in other works of Ibsen, appears at the beginning of the drama, and then takes the right sizes, in order to give the tragic, grotesque, and fatal aspect of the play. We can mention here the white horse symbol at Rosmersholm, the symbol of Wild Duck, the symbol at Ghosts, the symbol of the pistols at Heda Gabler, the symbol of the ring at The Lady from the Sea, the symbol of money at the The Doll's House, which have been treated in this writting.

The symbol of the sculpture here is associated with the loss and retrieving in an unfavorable time, as Rubek loses his muse at the time he wanted her most and finds her when she was less desired. The desire to retrieve is mixed with the satisfaction of rediscovering. The goal of Rubek is a life in symbiosis with Irene and the idea of his work 'Day of Resurrection', is strongly based on his artistic vocation.

Rubek: I need to live with someone to fulfil me... to compement me.... to feel one with him in everything I do. (McFarlaine, J.W. 1977:268)

In the second triangular connection, as we mentioned as more interesting, we find some anagnorisis, i.e. discoveries or renewed acquaintance. Firstly, a new dimension, that takes the conflict between life and art, can be mentioned. Rubek sees Irene in a different way, as Maja compares her to a statue.He reinforces the previous treatment of Irene as a sacrilege.

Rubek: Doesn't it look like the incarnated 'Resurrection'? (with himself) How is it possible that i have moved it? How did I leave it in the shadow? ... I changed it ...? Fool, fool! This is what I was! (McFarlaine, J.W. 1977:272)

A less but significant recognition, is found at the identification of the statue-image that Rubek sees while walking in the park at night. He was first urged by Maja when he guesses this figure would have been his model. Everything turns on and breaks in irritation in the troubled memories of Rubek, his lost merchandise, his idea of perfection that he has found at his model, as none of the silhouettes may coincide with his wholly pattern: 
Rubek: I have had a single model in my life! Only one, a single..... for everything I hve created! (McFarlaine, J.W. 1977:279)

As he recalls, he still observes in distraction the silhouette of that strange woman with a glass of milk in hand. And suddenly makes his most important discovery: 'I am recognizing you again, Irene' (McFarlaine, J.W. 1977:253) 'This shocking re-finding, gives that meaning that Rubek was looking for in Life and Art; In the utopia of this relationship he is surprised that Irene is still alive; exactly what gave life to his work 'with a desire so thrilling, with a passion so exalted'. (McFarlaine, J.W. 1977:271) The two protagonists are victims of triangular complex idea, with the third apex on top it is their 'baby', the Day of Resurrection. Rubek tells Irene that their 'child' remained unknown, never introduced to the public and in this way he has betrayed not only his vision, (McFarlaine, J.W. 1977:278) seen when Rubek confesses in Act II with a feeling of regret, longing and despair:

'My Vision for Resurrection: the most loved, the most beautiful image that I could have ever thought - was a young and pure woman, unspotted from the world, a woman who wakes up from the light and glory, and that there is nothing ugly or dirty from which she needs to relieve herself. '

but the art itself by denying the right to give life to it. In antagonism with this feminine virginity he has carved his sculpture as a 'Rodin Thinker' (Davis,2007) - a man humiliated by fault, placed at the foundation of the Resurrection Day. Anagnorisis or the other Recognition in this work comes through Irene when repulsed by attitude of Rubek and turns:

Irene: You killed my soul - then goes and shapes himself as a figure filled with remorse, pangs of conscience and repentance . (McFarlaine, J.W. 1977:279)

\section{Reversion dhe anagnorisis}

But the most important part is when reversion encounters recognition, which is the most unique feature of this drama, which interweaves in itself the complication of the relation between the subject and the characters. Act II begins with a long conversation between Rubek and Maja, who hides the aforementioned second subject until the 'small box' is mentioned. But when later Irene and Rubek stay near the cataract and the brook, then it is noticed that the tragic subject reached its culmination. Before this moment, we note that even Rubek and Irene felt a desperate emptiness in the creation of that great work of art, and both are somehow transformed with it:

Rubek: But that statue, with wet clay and lively .... that's what I wanted. As though a living soul, a child of man, came out of that large amount of shapeless material. She was our creation, our child. Mine and yours.' (McFarlaine, J.W. 1977:276)

Until now we are dealing with reversion, but just the confession of Rubek for his betrayal is associated with the recognition of the unknown. Irene's reaction towards this confession tells us that this is meeting point of peripetia with anagnorisis, of reversion disclosure.

After she killed her boredom, and did not call Rubek 'artist' but 'poet' in a disgusting way, it is clear that the work itself Day of Resurrection, their 'child' is betrayed and no longer exists. Here it is interesting to see the analogy with tragic at Rosmersholm, where in its culmination reversion meets the recognition through query techniques. This situation brings certain fatality, that's what expected to happen. Reversion at Rosmersholm happens at some stages, but in the end when he meets with recognition, i.e. its culmination, Mr. Rosmer discovers himself and his conversion through conversation with Rebekah. In rejection of the situation both of them have a fatal fate. 
What Ibsen brings after this moment is a confirmed failure of the identity of characters in parallel pairs. Irena suggest Professor Rubek to go to the mountain to spend a summer night together, which is the counterbalance of lure more successful than Ulfajm had with Maja, and this parallelism is in itself an expressed failure, as the Day of Resurrection that united the desires of Rubek and Irene did not exist. The reason why Ibseni expresses in the drama the desire that Rubek and Irena have to retrieve the lustful spark of their youth, the erotic attraction to each other, indicate the aim the loss of the subject itself. This is very clear at the end of the third act, in that pseudo erotic reunion in the mountains, where Irena express the depth of disappointment that accompanied in eternity:

Irena: The desire for living dead in me, Arnold. Now I am aroused. I am looking for you and I find you. Then I notice that you lie dead, and life lies dead. ... as well as I am dead. (McFarlaine, J.W. 1977:296)

\section{Catastrophe. Ambiguous scenic image}

In conclusion we can say that as the subjects had their reversion, in Act II loses tension and what happens in Act III is simply a confirmation of the failure of ideas, goals and objectives of the characters. At the drama When We Dead Awaken, and the other tragic dramas of Ibsen, we are not surprised or disappointed by the fatality of the protagonist, as in the case of the tragic fate of Rubek and Irene. Care should be taken not to embroider the drama with the contour of love stories and failure of marriage, which do not have a fundamental role, and even the appearance of this notion by the author. Its purpose is to present the characters' disaster, fatality, tragedy, vanity and the farce of existentialism, the failure of the Life and Art, creator and creation, and in no case it is important to perceive these as catastrophes of the subject.

In this text we have two triangular subjects combined with each other. Reversion is postponed in the background, while Recognition constitutes the element of structure within the structure, whereas Act III, impressive and very important, does not enrich the myth so much as the structural view is concerned. Can a reason be given to this? I think one of the reasons is that Ibsen is also the creator of a work of art, a dramatist, and most important for a creator is self-presentation of a work in an uninterrupted time, which means that the time of the work with the time of reading or staging remain unchecked. Time is also the time that passes between acts. It is important to note here I am referring to time as a universal notion, as an inseparable unit, and not the time length need by the author to write, the director to put it in stage or the reader to read it.

The drama When We Dead Awaken clearly shows that who wrong it may be to build a third time sequence from the very beginning of the Day of Resurrection. The age that should be given to Irene, as a dramatic character, remains undecided, because Rubek as well as Irene try to find a compromise. They do not agree on basic issues dealing with physical and spiritual existence itself, in their approach to each other. The strength of this text lies precisely in dramatic textual force, in a more attentive reading. Ibsen brings and recalls the Aristotelian drama elements in his way, as it is the case of the myth that appears in a second case, but always keeping in mind that it is not dominant in drama. Its text which comes through the characters should not be taken as the author's spokesman. Closure of the drama is ambiguous, but in my opinion it should be seen, as a major success of the expression of text, as the Ibsen-text that is presented in a complex image, which can not be explained, and not an image to be interpreted. The structure of the conclusion of the drama is a contradiction and an open issue.

End of drama is a scenic ambiguous image, similar to a musical work where the themes regather, but not reunite. These three elements in the drama When We Dead Awaken can be monitored in this way: first, when Rubek and Irena are seen in the distance, climbing the mountain's peak at sunrise and disappearing through snow avalanches, secondly, the moment when the maid enters and yells 'Irene!', as Rubek and Irena are disappearing in the snow, and thirdly, Maja apparently in Ulfajm's arms, heard singing her crazy song . Interruption with a comic element at the tragic point is a very fine feature of Ibsen's drama. In the combination of stage metaphor with the textual metaphor, one can notice the animal lust, the pure and sublime love, the sacrificing life, the betrayed art, which try to survive although too late for that. This is because artistic visions and hunting of bears are unifying and conflicting voices in this last stage metaphor of the drama. 


\section{Symbols` Parade. Action in drama}

In Ibsen's dramas the symbols overtake as changes in relevant drama itself. The injured Wild Duck despairs and melts in his siege, but eventually finds the thatched nest that others did for him, and finally he is sacrificed for the disaster of Ekdal family; The Lady from the Sea has the color and ringing of the sea; The ghosts have their footprints in the construction and completion of the hospital which finally gets flamed; Heda Gabler has its shiny but tough surface, and so on. The strong connection between the character, the subject and the symbol makes Ibsen's drama unique as well as pleasing in its style. In every drama the symbol is introduced in action, as we may re-mention Ghosts, where since the first act Regina and Engstrand discuss on the completion of the hospital; or at Rosmersholm where Lady Helseth mentions the white horse since the very first act too. These characters wander through the drama in a so mysterious and invisible manner, giving color and light to inner character. They reappear without being understood in different and unexpected moments. That's what happens at Wild Duck where the symbol reappears in the culmination of the drama for the last time and it is sacrificed by Hedvig. In exchange, Hedvig is sacrificed for Ekdal's family, the family for society as a whole, whereas the society itself is sacrificed for the social traditions that suffocate and refrain the man from the best and pure desires of life; the hospital at the Ghosts is set on fire at the critical moment when all the plans of Mrs. Alving are destroyed in her hands - The pastor Menders returns to her, Engstrand takes his prey and leaves, and so on. Mrs. Alving remains with the ruins of her personal life, which are burned out with her.

Because the action is the drama is psychological, its culminating point - i.e. psychological moment coincides with the moment of decision making. In each case we are dealing with a psychological battle: either short or long. Also with a turning point: either an acceptance of fate that has captured the character and given to him voluntarily, or a wild rebellion against this fate. The chance of psychological momentum and the symbol in the drama is so ubiquitous that it has become a special and brilliant feature of Ibsen's style of writing. The main symbol in the work, among many other possible symbols that come to light during deeper analysis of works of Ibsen, could be crucial in passing from the culmination point of action to the psychological moment. Ghosts is one of the dramas with greater presence of ghost-symbols, not just for reasons that shocked the public sensitivity by their appearance, but by building a sick state and the addiction of the society to its injuries, as venereal diseases and adultery. This drama is a damning indictment on outdated notions that were associated with the gender issues of the role of women in the family. Compared with the Doll House, the drama Ghosts does not portray a wife, but also a widow - mother at the same time, which fights against prejudice and bigotry of the time. Through this drama the author brings a new realism to the genre of drama and in the cheerless nature of its thinking. The strongest attack of the drama falls on 'sexual ownership' that spouses tend to keep on their wives, to whom the author provides human understanding on that part of society that still shackled after outdated ideas. Precisely this is the symbolic of the ghosts: dead but unburied dogmas and moral codes, that smell around us the disgusting smell of mold and rottenness, the broken thoughts that vivify in the corners of the collective consciousness. These are the ghosts that Mrs. Alving desperately wants to escape.

\section{Conclusion}

Here Ibsen affirms his greatness and compelling admiration that comes from the force that he has to deliver traditional principles in which people live freely in relation to themselves, as well as to force them to examine the roots or foundations of their moral and social opinions. (Howells, D.W., Vol. 183, Nr. 596) A brilliant, vital and lively drama that survives time, Ghosts is one of the most memorable plays of the early modern drama. Its focus to unravel family secrets in disregarding the hypocritical nature of a husband who was drunkard, immoral, perverse in the eyes of the community and of his children, was a taboo for the time. Mrs. Alving reveals the true reason for her son's disease: to her son's promiscuity inherited from his father. But it's too much to say that this promiscuity is inherited. There are other important factors that led Osvald to degradation 
of Osvald, that's for sure. Among most fervent wishes of Mrs. Alving is her son's happiness. He was sent a boarding school since his childhood, not to be influenced by the Captain Alving. When he returns she realizes the futility of departure, then she understands that this is hereditary. In antagonism with the symbol of Ghosts, Ibsen uses the symbol of the sun, which comes out in beginning of the play when Mrs. Alving promised to fulfill this desire of Osvald's childhood: to bring the sun and not despair, and, as it is mentioned in other dramas, this symbol returns at the end of the play when Osvald during his delirium requires the sun again, but hopeless now. The sun gives life and hope, the sun that provides death and heat.

In the analytical examination of drama it is to be noticed the spirit it reveals in its depth and content, concerning the censorship of conscience act, self-condemnation the uncomfortable complex of guilt. Manders and Mrs. Alving as characters make us shudder just for their innocence. Ibsen brought the time when we had to ask ourselves not to justice our motives but their wisdom. Analyzing the drama Ghosts, as well as The Lady from the Sea, one must understand that the individual should rethink in detail the sources of action and the basics of his obedience in order to act. All this thinking philosophy makes Ibsen writing unique, as well as in the perception of situations that he brings thanks to modern drama. What Ibsen asks the audience is not to consider the facts as his goal or target in order to convey the moral of his work, but to consider the overall result that the work leaves at the audiences, by using good sense. Let us take Mrs. Alving, who rebukes her former boyfriend for not accepting her return to him. On the contrary, Menders suggest she returns to her husband. Mrs. Alving then scolds herself for not feeling the lustful yearning for her husband, something which she experienced in illegitimate relationships. In the case of Mrs. Alving, Ibsen does not want to teach us, as readers, on the legitimate moral standards generally accepted as standards of behaving in society. In the opposite, he prefers to show us the characters movements by hitting us with high terror of the tragedy without a single hesitation, even by using all its possible and efficient ways.

\section{References}

Ibsen, Henrik 1977. The Oxford Ibsen.Ed. \& Transl. James Walter McFarlane, Vol. III. Oxford, London \& New York. Freud, S., Some Character Types Met with in Psycho-Analysis. 1916. Vol. 14, Art and Literature. Ibsen, Henrik 2000 (1972). Hedda Gabler. A new version by Christopher Hampton. London, Samuel French. Steiner, George 1982 (1961). The Death of Tragedy. London, Faber and Faber. Raymond, Williams. 1983 (1968) Drama from Ibsen to Breht. Penguin Books and Chatto \& Windus. Hollege, Julie \& Joanne Tompkins 2000. Women`s Intercultural Performance. London, Routledge. Girard, R. 1977. Violence and the Sacred. (La Violence et la Sacre'. Paris, 1972.) Baltimore. Maclntyre, Alasdair. 1985. After Virtue: A Study Moral Theory. Duckworth, London. Henrik Ibsen Author(s): W. D. Howells Reviewed work(s) The North American Review, Vol. 183, No. 596 (Jul., 1906), pp. 1-14 Published by: University of Northern lowa Stable URL: http://www.jstor.org/stable/25105589) www.classics.mit.edu http://www.thefreelibrary.com 
